\title{
高齢者施設利用者の生活環境ストレス認知尺度の開発 THE DEVELOPMENT OF A SCALE OF COGNITION OF THE STRESS OF LIVING ENVIRONMENTS IN THE ELDERLY AT INSTITUTIONS
}

\author{
入内島 一崇* \\ Kazutaka IRIUCHIJIMA
}

This study was designed to develop "A scale of cognition of the stress of living environments at institutions" using the elderly at health institutions for the aged subjects. Investigations were made at 9 of 37 institutions in Gunma Prefecture. As a result of statistical analysis, the status of cognition of the stress in the elderly at the aforementioned institutions was supposed to be a factor structure model (validity of contents), which consisted of the linear and the quadratic factors. The linear factor included "the stress factor of institution environment" (5 items), "the stress factor of freedom of living" (7 items), and "the stress factor of health administration" (2 items), and the quadratic factor included "cognition of the stress of the stress of living environments at institutions". It was also clarified that fit to the data (validity of constructs), the validity related to the standard, and reliability coefficient meets adequately the statistical tolerance level. From these results, the above-described scale was estimated to be beneficial to the future preparation of bases of health institutions for the aged in an aging society.

Key Word: elderly, stress, environment. 高齢者, ストレス, 環境

\section{I 目的}

従来、介護を必要とする虚弱あるいは寝たきり等の高齢者 1-2) の施設利用サービス 3)は、特別養護老人ホーム、養護老人ホーム、 老人保健施設等を拋点に展開されてきた。そのうちの老人保健施設 は、急性期の治療がすんだ老人の家庭復帰への橋渡しとしてのサー ビス機能を果たす機関として、1986 年の老人保健法改正 (施設は 88 年 4 月 1 日から施行）により制度化され、10 年余が経過したとこ ろである 3)。その施設運営において、(1)老人の心身諸機能の改善、 生活の質 QOL の向上を目指すこと、(2)入所機能と在宅支援機能を 有する施設であること、(3)看護、介護ケア、家庭復帰のためのリハ ビリテーション・サービスを提供する専門職員が配置されているこ となどが、厚生省「老人保健施設の設備及び人員並びに運営に関す る基準」4)に示されている。ゴールドプランは、平成 11 年度末 (1999 年）までに 28 万林を目標としているが、その後も継続して増数す ることが見込まれている 3)。上述したように、老人保健施設は入所 機能と在宅支嗳機能が幅広く付与され、それは病院でも福祉施設で もない「中間施設」として位置づけられるが、利用者にとってはあ くまでも「生活の場」である。従って、それは利用者にとってスト レスフルな環境であってはならないし、また生活舞境が個々人の QOLに反映されなければならない。しかし、老人保健施設は創設 されて間もなく、その環境整備に関する設備基準はあるものの、基
本的にどのような生活環境が利用者にとって望ましいかを検討し た研究 5-9）はほとんど見当たらない。

本研究は、老人保健施設利用者の QOL 向上に関連する環境整備 についての指針を得ることをねらいとして、環境建築学 10)の立場 から、利用者がその生活環境を物理的環境と生活する上での配慮に 関してどのように認知（評価）しているかを把握し、その程度を測 定するための尺度の開発を目的とした。

\section{II 方法}

調査施設は群馬県内 37 の老人保健施設のうち調查協力が得られ た 9 施設とし、また調査対象は、厚生省研究班の「痴呆スクリーニ ング基準」11)に依拠し、施設職員があらかじめ非該当と判断した 147 名とした。

調查内容は、基本属性（性、年齢、施設利用期間）、基本的 ADL、 生活環境におけるストレス認知（「設備・空間の利便性」く「居室 環境」と「共用環境」(「安全」「衛生」等を含む) >、「選択の自由、 「プライバシーの保護」)、ならびに「住んでいる場所（部屋）の快 適さ」）と精神的な健康状態とした。

これら調査内容のうち、基本属性と基本的 ADL に関するデー夕 収集は施設職員に依頼し、基本的 $\mathrm{ADL}$ は「バーセル・インデック ス」12)を用いて評価した。生活環境の認知に関する資料は、著者 のひとりが構造化された面接調査ですべてを収集した。その内容は、 
著者らの先行研究と従来 13）の研究業績 5-9)を参考に、「居室環境」 に関する 9 項目、「共用環境」に関連する 11 項目、「プライバシー 保護」に関する 6 項目で、さらに「選択の自由」に関する 20 項目 の、計 46 項目で把握した（表 1 )。前記 46 項目の回答は、ストレ ス認知理論 14-15）に従い、本人にネガティブな感情を䛈発するも のか否を、リカート 4 件法（「そう思わない」「時々そう思う」「し ばしばそう思う」「いつもそう思う」）で求めた。なおストレス認知 は、ラザルスのストレス理論に従うと「ある出来事を自分と無関係 とみるか、有益で肯定的なものとみるか、あるいはストレスフルな ものとみるかの評価（認知）を意味し、またストレスフルな状況 は否定的な感情と快の感情に大別されるが、本研究ではストレス反 応に大きく影響すると想定されるネガティブな感情を引き起こす生 活環境の倸価を扱う。

基準関連妥当性の検討の目的で測定した「住んでいる場所（部屋） の快適さ」に関しては、「全く快適でない」「あまり快適でない」「ど ちらでもない「「快適である」「非常に快適である」のリカート 5 件 法で回答を求めた。同様の目的から精神的健康状態を、「日本版 CES-D 尺度」16）Center for Epidemiological Studies Depression Scale で詽価した。CES-D 尺度は、Locke と Putmann13）が開発 した抑うつ諸症状 depressive

symptomatology を測定する尺度で、米国その他の国でよく使用さ れている。CES-D 尺度に対し探索的因子分析を最初に行った Radloff17）は、4つの下位因子（うつ感情、ポジティブ感情、身 体的症状、対人関係）を見いだし、その後それは欧米ならびにわが 国の高齢者において構成概念妥当性が確認されている 16,18-20)。

統計解析のフレームは、「居室環境」「共用環境」「プライバシー

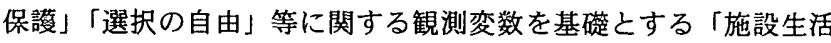
嘸境ストレス認知尺度」の開発をねらいに、まず第一段階として、 解析に投入する項目を選定するための一連の処理を行い、次いで第 二段階として、内容的妥当性の検討を目的とした因子構造モデルの 開発を試み、第三段階として、その因子構造モデルの構成概念妥当 性の検証を目的に確認的因子分析を行った。

前記第一段階では、まず最初に(1)デー夕識別力の高い項目を採用 することを目的に、周辺度数が明らかに偏った項目を削除した 21）。 このときの判断基淮は、「そう思わないの回答」が $95 \%$ 以上もしく は $5 \%$ 赤満とした。次いで(2)内部一貫性 22) を高める目的で、同 時複数項目削減相関係数法と同時複数項目削減主成分分析を行った。 このときあらかじめ仮定した因子の所属䉇囲で削除を行い、さらに それら因子の下位因子モデルを明らかにする中で、その下位因子に も属さないと推察される項目を削除した。なお、同時複数項目削減 相関係数法では、当該の項目得点と当該項目の得点を除く合計点之 の相関係数 Corrected Item -Total Correlation (以下「CITC」と 略す）が低い項目を削除するものとした。このときの削除条件は CITC が 0.3 以下とした。この手続きの後、(3)残った項目を主成分 分析に投入し、第 1 成分の負荷量が 0.3 以下の項目をすべて削除し た。以上の項目削除が完了した後に、さらに、(4)「室内環境」「共 用懐境」、「プライバシー保護」、「選択の自由」それぞれにあらかじ め割り当てた項目を用い、それら4つの領域での因子構造モデルを 整理することを通して、さらに不必要な項目の削除を行った。この とき因子解は最尤解を用いた斜交回転（プロマックス法）23）で求
めた。因子の解採は、固有值が 1 以上の因子に着目し、かつ絶対値 が 0.3 を超える因子負荷の推定値を参考に、因子の解䣋と不必要な 項目の削除を行った。

なお、以上の解析では最終的に開発される尺度への回答の簡便さ を考虑し、4件法で求めた回答を「そう思わない」を「満足：スト レス無し」として0点に、また「時々そう思う」てしばしばそう思 う」「いつもそう思う」を「不満 : ストレス有り」として 1 点に数 量化し、解析用の資料とした。

統計解析の第二段階として行った因子権造モデルの開発（内容的 妥当性の検討）では、前記解析で最終的に残った全項目に対し、再 度、同時複数項目削減相関係数法と同時複数項目削減主成分分析を 綳り返し、「施設生活睘境ストレス認知尺度」の因子構造モテルの 開発に必要な項目を選択した。そののち「施設生活環境ストレス認 知尺度」の因子構造モデルの開発をねらいとする探索的因子分析を、 最尤解を用いた斜交回転（プロマックス法）で行った。このときの 因子の解釈は上記の手続きに従った。

第三段階では、前記第二段階の探索的因子分析で得られた各因子 以外は因子負荷を０（ゼロ）に固定した検証モデルを措定し、その 適合度を共分散構造分析 24）で検討した。この解析は、前述の通 り確認的因子分析による構成概念妥当性の検討に相当する。適合度 指標は、説明力の程度として適合度指標「GFI」ならびに「RMSEA」 を採用し、安定性の程度として修正適合度指標「AGFI」を採用し た。GFI は一般的に 0.9 以上、また RMSEA は 0.08 以下であれば、 そのモデルがデータをよく説明していると判断される。なお RMSEA の検定は PCLOSE close fit で行った。

確認的因子分析で検証された因子構造モデルに属する観測変数の 信頼性は、潜在変数の因子得点と素点の合計点之の相関倸数の 2 乗 （決定係数）25)、ならびにクロンバックの $\alpha$ 信頼係数で検討した。 さらに、基準関連妥当性の検討には、外的基準として「住んでい る場所（部屋）の快適さ」と「CES-D 尺度」で測定した精神的健 康を用い、独立変数として施設生活環境ストレス認知に関連する得 点との関連性を相関係数で算出した。

以上の解析に用いた統計ソフトは、探索的因子分析に関しては 「SPSS」で、また確認的因子分析は「AMOS」26）で行った。な お、本研究では得られた 147 名の回答のうち、施設生活に関するス トレス認知のすべての項目に欠損值を有さない 126 名の資料を用い た。

III 绕罢

1. 属性等の分布

集計対象 126 名の性別構成は、男性が $23.0 \%$ 、女性が $77.0 \%$ で あった。全体の平均年齢は 81.8 歳、標淮偏差 5.96 であった。ADL 得点の平均は 67.8 点であった。年齢と ADL に性差は統計学的に認 められなかった。入所期間（有効回答 109 名）は、平均 8.7 ヶ月で あった。(表 1)

生活環境に関する回答は表 2 に示した。「不満 : ストレス有り」 とする回答頻度が多いのは「選択の自由」に関連する項目で、その うちで最も頻度が高かったのは「テレビ、ラジオ、ビデオが自由に 利用できない」(61.9\%) となっており、次いで、「新聞、雑誌、図 書が自由に利用したい」（55.6\%)、「ゆったりとした気分で入浴さ せてもらいたい」(54.8\%)、「外部と自由に通信（電話、ファック 
シミリ、手紙) できない」(54.0\%) で、これらが過半数を超えて いた。これに対し「設備・空間の利便性」く「居室環境」と「共用 環境」(「安全」「衛生」等を含む) >に関しては、「不満」とする回 答は比較的少なく、それが $20 \%$ を超えていたのは、「家族が宿泊し

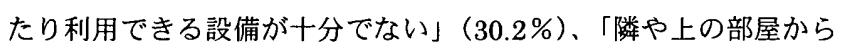
の話し声がうるさい」(27.0\%)、「部屋への風通しが悪い」

(21.4\%) の 3 項目であった。「プライバシー保護」に関連した項 目では、「家族や友人と落ち着いて会える場所（空間）がない」が $39.7 \%$ と最も「不満」が多く、「入浴時のプライバシー（裸体を他 人に見られる）が保護されていない」が $18.3 \%$ となていた。

「CES-D 尺度」で測定された精神的健康状態（有効回答 113 名） は、平均 17.0 点、標準偏差 8.89 点、範囲 1〜46 点であった。また 「住んでいる場所の快適さ」（有効回答 115 名）に関しては、「全く

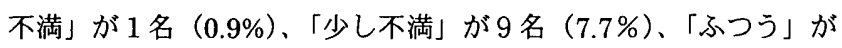
16 名 (13.7\%)「満足」が 59 名 $(50.4 \%)$ 、「非常に満足」が 30 名 (25.6\%)、不明が 2 名 (1.7\%) であった。

2.「施設生活環境ストレス認知」に関する囚子構造モデルの開発

1)「施設生活環境ストレス認知尺度」構成に必要な項目の選択

まず最初に、回答傾向から、周辺度数が $95 \%$ 以上であった「天 井が低く、息苦しい感じがする」を削除した。次にあらかじめ想定 した 4つの領域すなわち「プライバシ一保護」「居室環境」「共用環 境」「選択の自由」に属する項目ごとに CITC を算出し、0.3 以下の 項目の除外を行った。「プライバシー保護」の 6 項目では除外する 項目はなかった。選択の自由」に関する 20 項目では 7 項目が削除 対象となつた。具体的には「酒や夕バコなどの暂好品の制限が多い」 「お献立に自分の希望がかなえられない」「体の具合が悪いときで も、食事内容の変更が希望しにくい」「䯳型や服装が自分の好みで 選ぶことができない」「入浴日や入浴時間に制限が多い」「外食が自 由に注文できない」「施設内での行事に、強制的に参加させられる」 が削除された。また「居室眐境」に関する 8 項目では、2 項目（「隣 や上の部屋からの話し声がうるさい」「宓が小さいなど、太陽の光 が十分に取り込まれていない」）が削除対象となった。さらに「共 用環境」に関する 11 項目でも 2 項目（「家族が宿泊したり利用でき る設備が十分でない」「休や段差が滑りやすく危ない」）が削除対象 となった。次に前記の分析で残った項目を対象に想定した因子ごと に同時複数項目削减主成分分析を適用したが、削除条件を満たす項 目は観察されなかった。

次いで、さらに前記 4 つのあらかじめ想定した因子の下位因子を 検討することで、削除項目の観察を行った。「プライバシー保護」

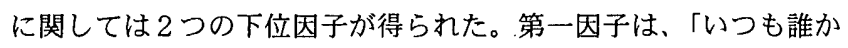
に見られていて、ひとりでゆったりできる時間が持てない」「ひと りで落ち着いた気持ちになれるような場所がごこにもない」「家族 や友人と落ち着いて会える場所がない」「ベットのまわりに仕切（カ 一テン) がないなど、自分の空間がない」で構成されており、「一 人の空間と時間」と解釈された。ただし「家族や友人と落ち着いて 会える場所がない」はその因子として解釈しにくいことから削除対 象とした。第二因子は「排泄時のプライバシー（他人に見られる） に対して、配慮が足りない」「入浴時のプライバシー（他人に見ら れる）に対して、配慮が足りない」から構成され、これはいずれも 「共用部分におけるプライバシーな空間」ということで共通してい
た。

「選択の自由」においては 13 項目を投入した。得られた下位因 子は 4つであったが、そのうちの 2 つの因子は所属項目がいずれも 1 項目から構成されていたことからそれらに所属する項目（「外出 の機会が、自由に認められない」と「ゆったりした気分で入浴させ てもらえない」）を除外し、またいずれの因子にも所属しない項目 であった「テレビ、ラジオ、ビテオが自由に利用できない」を除外 した。残りの 2 因子に所属する項目をみると、それは第一因子に相 当するが、「外部と自由に通信（電話、ファックシミリ、手紙）で きない」「新聞、雑誌、図書が自由に利用したい」「部屋の選択が希 望どおりできない」「お金を自分で管理できない」「私物を自由に持 ち込めない」の 5 項目が含まれ、それは「個人的なことに関わる選 択の自由」と解釈できた。ただし「部屋の選択が希望どおりできな い」はその概念からはかけ離れていると判断し除外した。また第二 因子には「地域への行事に参加しにくい」「レクリエーション活動 に自由に参加できない」「施設での行事に、家族や友人を参加させ

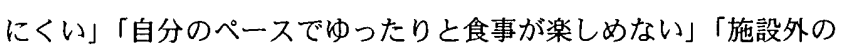
集まりに自由に参加できない」が含まれ、これは「地域あるいは人 との関わりに関連した選択の自由」と解积できた。しかし「自分の ペースでゆったりと食事が楽しめない」は、その概念として解釈す ることが困難なことから削除した。

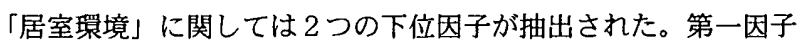
は「部屋の中の内装（床、天井、壁、カーテンなど）のいろどりが よくない」「ベットの大きさや堅さが自分に合っておらず、永心地 が悪い」「私物を収納する場所が自分にとって十分な大きさとなっ ていない」で構成され、これは「室内の個別性」と解釈できた。ま た第二因子には「すきま風が入ってきて不愉快」「室内の換気や温 度が快適に保たれていない」が所属し、これは「空調」と解釈でき た。なお、「部屋への風通しが悪い」は、ふたつの因子にほぼ等価 な因子負荷量を示していたことから除外した。

最後の「共用環境」に関しては、3つの下位因子が抽出された。 第一因子は、「地震に関する安全性に欠けている」「火災に対する安 全性に欠けている」「お風呂場の安全性に工夫が足りない」の 3 項 目からから構成され、「安全性」に関連した因子と解积できた。第 二因子には「お風呂場が不潔でいやな感じがする」と「トイレが臭 うなど清潔さに欠けている」が所属し、これは「衛生」に関連した 因子と解釈できた。第三因子は「車椅子等による移動がしにくい設 計になっている」「ディルームや談話室がくつろげる空間（広さや 間取りを含む）になっていない」「障害を考虑したトイレの設備・ 改善が不十分である」からなり、「障害への配慮」と解釈できた。 ただし「洗面所が自分にとてっは使いにくい構造となっている」は いずれの因子にも属してないことから除外した。

以上の結果、当初に設定した 4 つの領域において特定の下位概念 （因子）に所属すると認識された 24 項目（表 2 ）を、「施設生活睘 境ストレス認知尺度」開発に必要な項目として選定した。

2 ）「施設生活環境認知」に関する因子構造モデルの開発

探索的因子分析に先立ち、前記分析で得られた 24 項目（表 3) の CITC を求めたところ、 8 項目が 0.3 以下の数值を示した。ただ し 2 項目については 0.293、0.296 となっていたことから削除せず、 残りの 18 項目について主成分分析を行ったところ、第一主成分の 
因子負荷量が 0.3 以下の項目は観祭されなかった。

そこで前記 18 項目を用いて、総合的な「施設生活環境ストレス 認知尺度」の構築をねらいとした因子構造モデルの開発を企図し、 最光解を用いた斜交回転（プロマックス法）で因子解を求めた。そ の結果、3つの因子が抽出された（表 4)。ただし、「地域への行事 に参加しにくい」と「私物を自由に持ち込めない」のふたつは、因 子負荷量が 0.3 に満たないこと、また「部屋の中の内装（床、天井、 壁、カーテンなど）のいろどりがよくない」は第一因子と第三因子 に所属していたことから除外して因子の解䣋を行った。

第一因子には「火災に対する安全性に欠けている」「地震に関す る安全性に欠けている」「室内の換気や温度が快適に保たれていな い」「障害を考慮したトイレの設備・改善が不十分である」「部屋へ の風通しが悪い」「施設外の集まりに自由に参加できない」の 6 項 目が所属していた。「施設外の集まりに自由に参加できない」を除 くと、この因子は『設備環境ストレス因子』と解䣋できた。

第二因子には、「いつも誰かに見られていて、ひとりでゆったり できる時間が持てない」「ひとりで落ち着いた気持ちになれるよう な場所がどこにもない」「ベットのまわりに仕切（カーテン）がな いなど、自分の空間がない」「施設での行事に、家族や友人を参加 させにくい」「新聞、雑誌、図書が自由に利用したい」「レクリエー ション活動に自由に参加できない」「お金を自分で管理できない」 の 7 項目が所属していた。この因子は『生活自由度ストレス因子』 と解䐆できた。

第三因子には「お風呂場が不潔でいやな感じがする」と「トイレ が臭うなど清潔さに欠けている」の 2 項目が属していた。この因子 は『衛生管理ストレス因子』と解䣋できた。

3.「施設生活環境ストレス認知尺度」に関する構成概念妥当性の 検討

前記の解析から、本研究では 3 因子 14 項目からなる二次因子モ デル（図 1) を設定し、その因子構造モデルのテータへの適合度を 検討した。GFIは 0.905、RMSEA は 0.045（PCLOSE=0.585）で、 AGFI は 0.865 であった。このときの潜在的因子（第一次因子）か ら観測変数への標準化係数（「パス係数」）は、いずれも正值であっ て、「設備環境ストレス因子活動」は 0.442 0.719、「生活自由度ス トレス因子」は 0.348〜0.747、「衛生管理ストレス因子」は 0.649 〜0.970 の䈇囲にあった。裹却比である F 值はすべて 1.96 （5％有 意水準）以上となっていた。なお、誤差分散に統計学的に有意な水 準で相関がある誤差間に相関を認めた因子構造モデルでは（y3 と y18、y3 と $\mathrm{y} 17 、 \mathrm{y} 4$ と $\mathrm{y} 17) 、 \mathrm{GFI}$ は 0.916、RMSEA は 0.037 （PCLOSE=0.739）で、AGFIは 0.876 と改善された。

4.「施設生活環境ストレス認知尺度」の信頼性の検討

以上の解析から、著者らは 14 項目から構成される施設環境にお けるストレス認知に関する測定尺度を「施設生活環境ストレス認知 尺度」と命名し、信頼性係数について検討した。

信頼性係数は、前記 14 項目の素点（「そう思わない」を0点に、 また「時々そう思う」「しぱしばそう思う」「いつもそう思う」に1 点）の合計点を従属変数、またその各項目の得点にパス係数を乗じ て算出した二次因子の得点を独立変数としたときの寄与率を求めた ところ、それは 0.979 (寄与率 97.9\%) となった。さらにクロンバ ックの $\alpha$ 信頼性係数については、14 項目全体で 0.743、「設備環境
ストレス因子」は 0.663、「生活自由度ストレス因子」は 0.698、「衛 生管理ストレス因子」は 0.770 であった。

各質問項目の素点の合計点に関する分布を見ると、「施設生活環 境ストレス認知」の平均が 3.7 （標準偏差 2.83）で、尖度は 0.997 、 歪度は 1.333 であった。

5.「施設生活環境ストレス認知尺度」の基準関連妥当性の検討

施設生活環境ストレス認知に関する総合得点(「施設生活環境ス トレス認知」の素点合計）と「住んでいる場所（部屋）の快適さ」 との関連性は、ピアソンの相関係数で-0.274（p<0.01）となり、こ れを因子別に見ると「設備環境ストレス因子」は-0.267（p<0.01）、 「生活自由度ストレス因子」は-0.053、「衛生管理ストレス因子」 は-0.327（p<0.01）となっていた。また精神的健康度（CES-D 得 点）と「施設生活環境ストレス認知」の総合得点との間には統計学 的に関連性が認められなかったが、「設備環境ストレス因子」とは $0.185 （ \mathrm{p}<0.01 ）$ の相関を示した。なお、前記ストレス認知に関す る総合的な素点の合計点、ならびに因子別の素点の合計点は年齢な らびに入所期間と関連性はなく、また平均得点には統計学的にみて 性差は認められなかった。

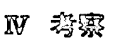

本研究は、老人保健施設の QOL 向上のための環境整備に関する 指針を得ることをねらいとして、施設利用者が生活環境から受けて いるストレス 14-15）を、物理的環境と生活する上での配慮の側面 から把握し、その程度を測定するための尺度開発を目的として行っ た。構成概念を基礎とする尺度開発に当たっては、概念規定に基づ く調㚗項目の設定、調㚗、開発を企図した尺度の内容的妥当性を因 子構造モデルとして明確にし、またその因子構造モテルに共分散構 造分析を適用させ、構成概念妥当性を検証していくことが必要であ る 21）。また開発された尺度の意義を基準関連妥当性の検討を基礴 に明らかにする必要もある21）。さらにこれら妥当性の検討に加え、 信頼性に関する検討も必要である 21)。本研究は、それら尺度開発 に必要な一連の作業を、老人保健施設で発現する利用者のストレス に視点をあて、それを生活睘境との関連で抽出することを試みた。 なお、ストレス認知は本人の確かな評価を前提にすることから、本 研究においては明らかに痴呆症状が観察される高齢者はあらかじめ 調査対象から除外した。また最終的な尺度の開発に必要な項目の選 択には、識別性と内部一貫性の検討を繰り返し検討したが、これは 尺度開発にとって適切であったと推察される。

その結果、「設備環境ストレス因子」「生活自由度ストレス因子」 「衛生管理ストレス因子」を一次因子、「施設生活環境ストレス認 知」を二次因子とする「施設生活環境ストレス認知尺度」を開発す ることができた。その調㚗項目数は、「設備環境ストレス因子」が 5 項目、「生活自由度ストレス因子」が7項目、「衛生管理ストレス 因子」が 2 項目の計 14 項目で構成され、因子構造は二次因子モテ ルとなっている。この措定された因子構造モデルのデータへの適合 度は GFI が 0.905、RMSEA が 0.045（PCLOSE=0.585）で、AGFI は 0.865 であった。本研究では先行研究の成果 13)を基礎に、あら かじめ「設備・空間の利便性」「選択の自由」、プライバシーの保 護」に関連する 46 項目をプールし、その識別性や内部一貫性を慎 重に検討することで不必要な項目を削除し、前記因子構造モデルを 仮定した。これら一連の解析は内容的妥当性の検討に相当するが、 
仮定された因子構造モデルのデータへの適合度が統計学的な許容水 準にあったことは、「施設生活睘境ストレス認知尺度」の構成概念 妥当性を支持するものである。また、「施設生活環境ストレス認知 尺度」の二次因子構造モデが検証されたことは、観測変数が一次 因子においてそれぞれ加算性が保証されるだけでなく、三次因子と して想定した「施設生活環境ストレス」として、観測変数をすべて 加算できることを意味する。ちなみに本研究で開発した「施設生活 睘境ストレス認知尺度」の信頼倸数は、14 項目全体で 0.743、「設 備環境ストレス因子」は 0.663、「生活自由度ストレス因子」は 0.698 、 「衛生管理ストレス因子」は 0.770 となっており、実用的な使用に 十分臫えられるものと推察された。

なお、著者らの先行研究においては、すでに施設生活におけるス トレス認知の要素として 3 つの概念（「選択の自由」「設備の利便 性」「生活上の配慮」）を主成分分析により抽出できていた。しかし、 それら要素が相互にどのような関係にあるか、換言するなら、相互 に関連性を持ちながらも独立した関係にあるのか（斜交因子モデ ル)、あるいはさらに上位概念としての生活環境の認知に統合され るのか（二次因子モデル）、さらにはそれら 3 つの側面が特定の概 念を下位概念として有する概念なのか等については、対象数の関係 から検討できなかった。本研究の結果はその問題に対しての回答を 与えるものであり、今後、施設利用高龄者の QOL を考える上で大 きな役割を果たすものと期待される。この点については、以下に述 べる基準関連妥当性の検討によって裹付けられたと推察される。

本研究では、内容的妥当性ならびに構成概念妥当性の検討に加え、 基準関連妥当性の検討として、前記尺度で得られた素点の合計点な らびに下位因子ごとの素点合計点と「住んでいる場所（部屋）の快 適さ」および「精神的健康状態」との関連性を解析した。その結果、 「住んでいる場所（部屋）の快適さ」に関しては、「施設生活環境 ストレス認知」に関する総合得点ならびに「設備環境ストレス因子」 および「衛生管理ストレス因子」と密接に関連していることが明ら かにされた。また、精神的健康度（CES-D 得点）とは、「設備環境 ストレス因子」が関連していた。なお、「生活自由度ストレス因子」 は「住んでいる場所（部屋）の快適さ」とは関連性が認められなか った。これら結果は、ストレス認知の程度がストレス反応に影響す る 14-15）という因果関係を、従来の研究ではほとんど扱われてこ なかった高踰者の施設生活におけるストレス認知、とりわけ物理的 環境から派生するネガティブなストレス認知が、ストレス反応とし て位置づけられる精神的健康状態に関連するという文脈において成 立する、というかたちで実証したことを意味する。以上の結果は、

「施設生活環境ストレス認知」を測定することの意義、すなわち基 準関連妥当性を裹付けるものである。

ところで、従来の研究では、精神的健康状態が QOL に大きな影 響を持つ27）ことが指摘されている。また QOL に関連するさまざ まな要因が在宅の高龄者 28)を中心に検討が加えられてきた。他方、 施設利用の高齢者の QOL を検討した業績 29-31)は多くはないが、 施設に入所すること自体が利用者にとってストレスになり、それが 利用者の QOL に影響を与えることが想定されていた 32 )。しかし 施設生活環境の何がストレス反応を引き起こすかを十分に検討した 報告は見当たらないかった。その意味で、それを「施設生活環境ス トレス認知」として把握できる尺度が開発できたことは、本研究の
大きな成果と言えよう。

また、著者らが「設備睘境ストレス」と命名した因子の観測変数 （調查項目）からも明らかなように、「火炎に対する安全性に欠け ている」「地震に関する安全性に欠けている」「室内の換気や温度が 快適に保たれていない」「障害を考慮したトイレの設備・改善が不 十分である」「部屋への風通しが悪い」といったことに対する配慮 は、建築学的には欠かせない重要な要素であり、さらに「お風吕場 が不潔でいやな感じがする」と「トイレが臭うなど清潔さに欠けて いる」といった「衛生管理ストレス因子」に関しても、建築上十分 な配慮が必要な内容となっている。臭気や換気に対する意識 33-35） は、すでに一般あるいは高層住宅関連で指摘されていたことである が、このことは当然老人保健施設の高齢者にも適用されなければな らないものと言える。従来、施設評価は「特別養護老人ホーム・老 人保健施設のサービス評価基準」36）として作成されてきた。しか し、それはあくまでも利用者による評価ではなく、施設管理者によ る施設の自己評価にとどまるもので、それが利用者にどう反映する かについてはほとんど検討されてこなかった。特に、本研究で前述 の内容が明らかにできたことは、「もの」あるいは「うつわ」とし ての施設環境評価にとって、施設側の評価のみならず、利用者本人 の評価を重視しなければならないことを示唆するものである。近年、 急速な高齢化と家族介護力の低下に伴い、特別養護老人ホームや老 人保健施設を利用する高齢者が増大している 3) ことを勘案するな ら、その概念の尺度化は大きな成果と推察される。

以上、本研究においては、高齢者の施設生活におけるストレス認 知を、「設備環境ストレス因子」「生活自由度ストレス因子」「衛生 管理ストレス因子」を下位概念として抽出できることを明らかにし た。今後の課題としては、さらに「施設生活環境ストレス認知尺度」 の因子不変性について検討を加えることが尺度の構成概念妥当性を 確認する上で重要な課題であり、加えて、測定結果が QOL の向上 に反映されることが重要な課題と言えよう。

\section{表 1．集計対象者の基本属性}

\begin{tabular}{lllllll} 
性別 $(n=126)$ & 男性 & $29(23.0 \%)$ & 女性 & $97(77.0 \%)$ \\
年龄 $(n=120)$ & 平均 & 81.8 歳、標準偏差 & 5.96 & 範围 & $69-95$ \\
\hline ADL 得点 $(N=115)$ & 平均 & 67.8 & 標準偏差 & 25.2 & 範围 & $5-100$ \\
\hline 入所期間 $(n=109)$ & 平均 & 8.7 ケ月 標準偏差 & 12.0 & 範囲 & $1-84$ \\
\hline
\end{tabular}


表 3 選択された 24 項目（信頼係数 : CITC） 調查項目

\begin{tabular}{|c|c|c|}
\hline 1 & 火災に関する安全性に配慮が久けている & .4113 \\
\hline 2 & 地震に関する安全性に配慮がたりない & .2961 \\
\hline 3 & トイレが基うなど清海さに久けている & .3229 \\
\hline 4 & お風呂場か不潔でいやな感じがする & .4532 \\
\hline 5 & すきま風がつてきて不愉快 & .2815 \\
\hline 6 & 室内の換気や温度が快適に保たれていない & .3778 \\
\hline 7 & $\begin{array}{l}\text { 室の中の内装 (床、天井、壁、カーテンなど) } \\
\text { のいろどりがよくない) }\end{array}$ & .4035 \\
\hline 8 & 部屋への風通しが悪い & .3357 \\
\hline 9 & $\begin{array}{l}\text { 障害を考虑したトイレの整備・改造が不十分で } \\
\text { ある }\end{array}$ & .3537 \\
\hline 10 & $\begin{array}{l}\text { 私物を収納する場所が自分にとって十分な大き } \\
\text { さとなつていない }\end{array}$ & .2018 \\
\hline 11 & $\begin{array}{l}\text { 車椅子等による移動がしにくい設計になってい } \\
\text { る }\end{array}$ & .2459 \\
\hline 12 & $\begin{array}{l}\text { 入浴時のプライバシー（裸体を他人に見られる） } \\
\text { が、保護されていない }\end{array}$ & .2086 \\
\hline 13 & $\begin{array}{l}\text { 排泄時のプライバシー（他人に見られる）に、 } \\
\text { 配慮が足りない }\end{array}$ & .2211 \\
\hline 14 & $\begin{array}{l}\text { ひとりで落ちついた気持ちになれるような場所 } \\
\text { がどこにもな }\end{array}$ & .3438 \\
\hline 15 & $\begin{array}{l}\text { ベッドのまわりに仕切（カーテンなど）がない } \\
\text { など、自分の空間がない }\end{array}$ & .3908 \\
\hline 16 & $\begin{array}{l}\text { いつも誰かに見られていて、ー人でゆったりで } \\
\text { きる時間が持てない }\end{array}$ & .4298 \\
\hline 17 & お金を自分で管理できない & .3731 \\
\hline 18 & 新聞、雑誌、図書が自由に利用できない & .3597 \\
\hline 19 & 地域への行事に参加しにくい & .3489 \\
\hline 20 & 私物を自由に持ち込ない & .3279 \\
\hline 21 & $\begin{array}{l}\text { レクリエーション活動 (クラブ活動等) への参 } \\
\text { 加が自由に選択できない }\end{array}$ & .3738 \\
\hline 22 & 施設での行事に、家族や友人を参加させにくい & .4007 \\
\hline 23 & 施設外の集まりに自由に参加できない & .2925 \\
\hline 24 & $\begin{array}{l}\text { 外部と自由に通信（電話・ファクシミリ・手紙） } \\
\text { できない }\end{array}$ & .2824 \\
\hline
\end{tabular}

\section{表 4 選択された 18 項目でのパターン行列}

調查項目

因子負荷量

\begin{tabular}{|c|c|c|}
\hline 1 & 火災に関する安全性に配慮が欠けている & .743 \\
\hline 2 & 地震に関する安全性に配慮がたりない & .572. \\
\hline 6 & 室内の換気や温度が快適に保たれていない & .457 \\
\hline
\end{tabular}

9 障害を考慮したトイレの整備・改造が不十分で .409 ある

8 .

83
23

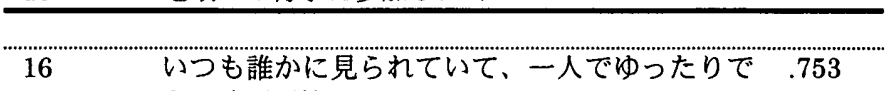

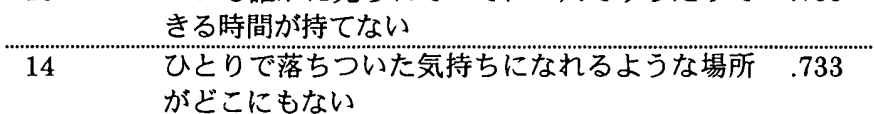

15 ベッドのまわりに仕切（カーテンなど）がない .507 など.自分の空間がない

\begin{tabular}{|c|c|c|}
\hline 22 & 施設での行事に、家族や友人を参加させにくい & .433 \\
\hline 18 & 新聞、雑誌、図書が自由に利用できない & .325 \\
\hline 21 & $\begin{array}{l}\text { レクリエーション活動 (クラブ活動等) への参 } \\
\text { 加が自由に選択できない }\end{array}$ & .323 \\
\hline 17 & お金を自分で管理できない & .304 \\
\hline 20 & 私物を自由に持ち込めない & ……. \\
\hline
\end{tabular}

\begin{tabular}{|c|c|c|}
\hline 3 & トイレが具うなど清潔さに欠けている & .868 \\
\hline 4 & お風呂場が不海でいやな感じがする & .723 \\
\hline 7 & $\begin{array}{l}\text { 室の中の内装 (床、天井、壁、カーテンなど) } \\
\text { のいろどりがよくない }\end{array}$ & .477 \\
\hline
\end{tabular}

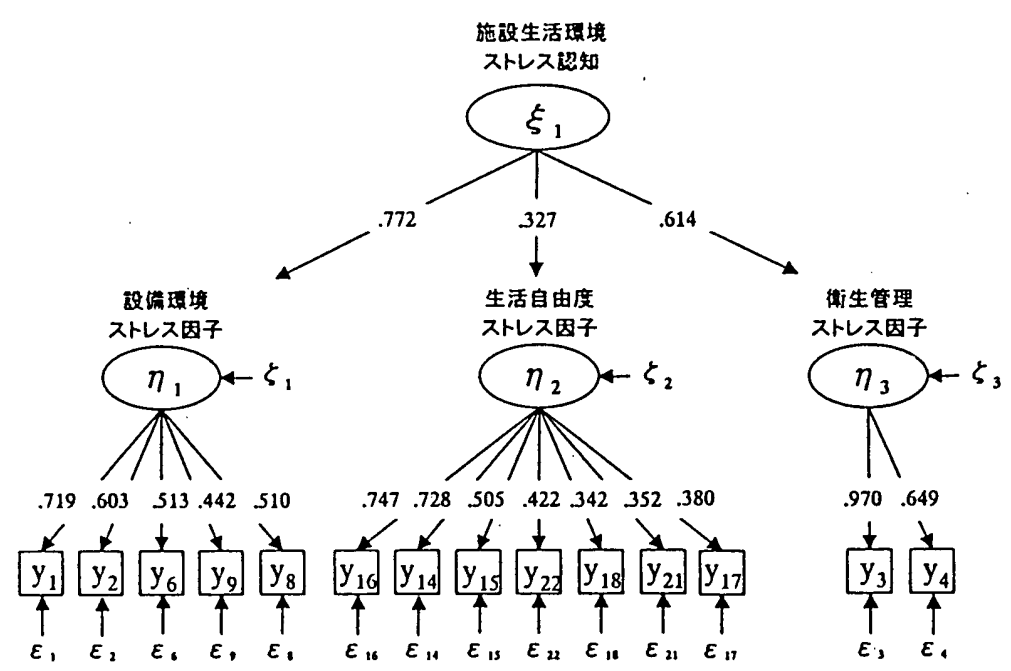

图 1 施設生活環境ストレス認知尺度の因子構造モテル(標準化係数) 


\section{文献}

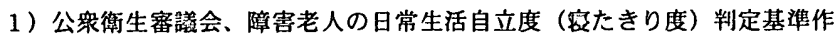
成検討会報告费、公采衛生情報、1、42-45、1992.

2）厚生統計協会 : 保険と年金の動向，厚生統計協会，1998.

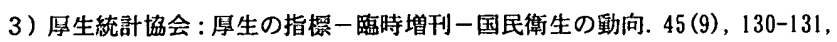
1998.

4）厚生省令 : 老人保健施設の設備及び人員並びに運営に関する基準」、1990

5 ) 高橋正樹・宮田紀元：居住瑟境評価における評価の観点の研究. 日本建 築学会計画系諭文集、488、85-92、1996.

6）川口孝泰・相井利枝・松浦和幸・勝田仁美・根本消治・南裕子 : 構造モ テルを用いた入院患者の㗍境認知特性の把握. 看讙研究、30(4)、264-272、1997. 7) 服部朝子 : 病室や病棟琹境に対する患者の認知. 看謨研究、24 (2)、117136. 1991.

8 ）渡辺圭子：住環境と絙神健康に関する研究. 建設省建策研究所研究報告、 $101 、 11-20 、 1982$.

9) 中村洋一 : 病院空間の視敩的印象の分析. 病院管理、21 (3)、57-67、1984

10）不村建一：建筑棵境学 2. 丸善株式会社、1993.

11）西村健：族呆の診断基準. Geriatric Medicine，30(6)，881-887, 1992.

12) Mahoney, FI. and Barthel, DH. : Functional evaluation: The Barthel index. Maryland State Medical Journal, 14, 61-65, 1965.

13）入内島一崇・崒身孝雄：施設高踰者における生活琵境の認知的評価と主 䚁的 QOL との関俰. 東京保健科学学会誌、2(1)、46-51、1999.

14) Lazarus, RS. and Folkman, S.: Transaction theory and research on emotions as coping, Eur J Pers, 1, 141-169, 1987.

15) Lazarus, RS. and Smith, CA.: Knowledge and appraisal in the cognition-emotion relationship. Cog Emo, 2, 281-300, 1988.

16）矢富直美・ Jersy Liang - Neal Krause - Hiroko Akiyama : CES-Dによ る日本老人のうつ晸状の測定一その因子棈造における文化差の検討一，社会 老年学, 37, 37-47, 1993.

17) Radoff, LS: The CES-D scale: a self-report depression scale for research in the general population. Appl Psychol Measurement, 1, 385$401,1977$.

18) Hertzog, C., Van Alstine, J., Usala, PD. Hulstsch, DF. and Dixson, R. : Measurement propaties of the Center for Epidimiologic Studies Scale (CES-D) in older populations. Psycological Assessment, 2, 64-72, 1990. 19) Dividson, H,. Feldman, PH. and Crawfold.: Measuring depressive symptoms in the elderly. Journal of Gerontology, 49(4), 159-164, 1994. 20) McCallum, J., Mackinnon, A., Simons, L. and J.: Measurement propaties of the Center for Epidimiologic Studies Depression Scale: an Austrarian community study of aged persons. Journal of Gerontology, 50B(3), 182189, 1995

21）古谷野亘 : 実証研究の手引き.ワールドプランニンク゚、1997

22）服部照：テストの内部一其性を大きくするための項目選択技法. 教育心 理学研究, 39, 195-203, 1991.

23）柳井晴夫・珐桝算男・前川发一・市川雅教 : 因子分析一その理論と方法

一。朝倉書店, 東京, 1990 .

24）豊田秀臌 : 共分散㩐造分析の下位モテルとその適用例. 教育心理学研究, 39 (4) , 103-114，1991.

25）池田央：調查と測定. 新曜社, 東京, 1980.

26) Arbuckle, JL.: Amos user's guide version3.6. Chicago, SmallHaters
Corporation, 1997.

27）浜岛ちさと:高龄者のクオリティオブライフ. 日本衛生学雑誌, 49, 533-542, 1994.

28）藤田利治、大塚俊男、谷口幸一：老人の主锶的幸福感とその関連要因. 社会老年学, 29, 76-85, 1989.

29) Folk, S and Telleen, S: Psychological and social correlates of life stisifactionas a function of residental constraint. Journal of Gerontology, 31(1), 89-98, 1976.

30）與古田孝夫 : 施設入所老人の主観的幸福感とその関連要因についての検

討. 日本精神保健看護学会誌，4(1)，37-46，1995.

31）蛯江紀雄：老人ホームにおける老人のQOL．老年䄇神医学雑誌，4(9)， 993-998, 1993.

32）小山内隆生・加藤抧彦・杼口信子・鈴木吉八郎：青森県の老人保健施設

に入所中の老人の抑うつ. 作業療法、16(3)、209-214、1997.

33）松井静子・楢崎正也・中山俊夫・平石弘 : 住宅内の臭気塄境及び居住者 の臭気に対する意韵の実態. 日本建築学会計画系論文報告集、452、19-25、1993.

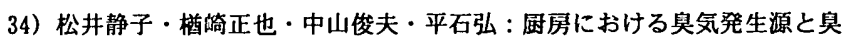
気評価. 日本建策学会計画系論文報告集、460、31-38、1994.

35）水谷国男・岩瀬昭雄・赤林伸一：新潟市の中居集合住宅における温熱空 気聚境に関する調查報告. 日本建策学会計画系論文報告焦、407、27-36、1990.

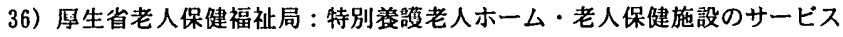
評価基準．全国社会福祉協讙会，1994.

(2000年 1 月 6 日原稿受理，2000年 3 月 21 日採用決定） 